\title{
ECONOMIC INDICATORS OF GOAT BREEDING ON FAMILY HOLDINGS IN THE REPUBLIC OF SERBIA
}

\author{
Zorica Sredojevićl, Tamara Vujić ${ }^{2}$, Miroslav Jevremović ${ }^{3}$ \\ *Corresponding authorE-mail: zokas@agrif.bg.ac.rs
}

A R T I C L E I N F O
Original Article
Received: 15 November 2020
Accepted: 11 December 2020
doi:10.5937/ekoPolj2004297S
UDC 631.815:[636.3:631.1.017
3(497.11)

Keywords:

goat breeding, farm, kids, milk, economic parameters

JEL: Q12, Q19, D24

\section{A B S T R A C T}

The subject of research in this paper is the analysis of economic indicators of goat breeding. Based on the data of the FAO and SORS statistical databases, the situation in the goat sector in the world, Europe, the EU and the Republic of Serbia was examined. Based on the set goal of the research, important questions were answered, such as: What amount of profit can he expect from goat breeding? Is such production economically justified and for how long can the financial investments be returned and at what rate of accumulation? Based on the inputs and outputs of Alpine and Balkan goat breeding (farm 2) in Serbia, more important economic indicators have been determined. The average profit ranges from 9,783€ (farm 1) to $18,208 €$ (farm 2 ), and the invested capital can be returned in the first or second year of goat breeding. At $100 €$ of invested capital, from $55.27 €$ to $102.85 €$ of accumulation is achieved, which depends on the breed of goats. Goat breeding is economically justified for breeders and provides significant financial security and economic sustainability of the holding.

(C) 2020 EA. All rights reserved.

\section{Introduction}

In developed countries, livestock production has a dominant share in total agricultural production, so it is also an indicator of the quality of the overall condition of the primary food sector. In the same countries, products of animal origin dominate the diet of the population, which leads to the conclusion that the consumption of animal products, with the growth of standards, is growing both quantitatively and in terms of value (Sehested et al., 2000).

1 Zorica Sredojević, Ph.D., Full Professor, University of Belgrade, Faculty of Agriculture, Nemanjina 6, 11080, Zemun, Serbia, Phone: +381 114413 297, E-mail: zokas@agrif. bg.ac.rs, ORCID ID (https://orcid.org/0000-0001-7224-1573)

2 Tamara Vujić, MA, UTD Narcis Divčibare doo, Vojvode Mišića street no. 2, 14000 Valjevo, Serbia, Phone: +381 6922720 59; E-mail: tim.hot.vujic@gmail.com ORCID ID (https:// orcid.org/0000-0002-5445-4222)

3 Miroslav Jevremović, Ph.D., Faculty of Business and Law, Knez Mihailova street no. 33, 11000 Belgrade, Serbia, Phone: +381 640028 388; E-amil: adm.tfc@gmal.com

http://ea.bg.ac.rs 
Breeding of ruminants is based on the maximum use of grazing, and in accordance with the available pasture areas at different times of the year. Small cattle, small ruminants, are mainly reared according to known methods on pastures in areas where the position of the terrain is unfavorable for intensive agricultural production (Pavličević et al., 2000). They play a key role in landscapes and biodiversity conservation. Opportunities to improve the sheep and goat sector may also stem from the need to conserve natural resources. Goats are suitable for breeding on areas less accessible to other species of animals, and also as users of by-products of the field and processing industry - straw and other crop residues.

Goats graze and browse weeds and other different plants, clean and fertilize the areas under plant cultures, encouraging the growth of desirable vegetation. This way of cleaning surfaces has already given significant results in some regions (Australia and New Zealand) and countries (Greece and Spain). It has proven to be very effective, cheap and environmentally friendly, in contrast to significantly more expensive and environmentally harmful, mechanical and chemical surface cleaners (Kitsopanidis, 2000).

The connection between farming and goat breeding is reflected in the fact that goats produce significant amounts of high quality manure during the winter, without which it is difficult to achieve higher yields in farming. This is important in today's conditions of disturbed ecosystem, when the important task of any development program is to preserve the environment (Stojanović et. al, 2004). In such ecological conditions, more biologically valuable food is produced.

Combined grazing is a form of pasture exploitation in which several types of livestock are combined. Most often they are cattle and sheep or goats, where the utilization rate of pastures increases by 35\% compared to grazing only cattle (Ocokoljić et al., 1983; Coffey et al., 2001). Meat production increases in combined grazing of sheep or goats with cattle by $24 \%$ in relation to grazing only in cattle, and by $9 \%$ in relation to grazing only in sheep or goats (Wells et al., 2000).

Production systems in the Republic of Serbia in sheep and goat breeding are not largely differentiated and it can be said that there are generally two systems in both branches. In sheep breeding, these are small farms for the production of lambs with the use of grazing and without it, and in goat breeding, a system of small farms for the production of milk and kids with the use of grazing without it. Based on the examination of the milk traits of Balkan goats in semi-extensive breeding conditions, it can be concluded that these traits contain enough phenotypic variability for the selection to be successfully performed on them (Bogdanović et al., 2008).

The advantages of goat breeding in relation to other branches of animal husbandry are reflected in: lower level of initial investments, large areas of unused pastures, nutritional advantages of goat milk, lower intensity of work operations, etc. The size of the herd depends on the production goal, the breeding system (extensive, semi-intensive and intensive), the breed and the availability of agricultural land, as well as on the fact whether it is the basic or additional activity of the household. In combined production, meat - milk 
- cheese, the number of breeding heads may be slightly lower. In our country, experts often recommend the production of meat and milk, which is based on the existing racial structure, but with significant improvements in all segments of goat breeding. The commitment to goat breeding and profitability of production depends on numerous factors, which include the availability of food, the required land area, animal housing facilities, market availability, the price of raw materials and products on the market, supply, demand, etc. An important factor for the success of goat production is the facilities, as well as their equipment. It all depends on the breeding system and the racial composition of the goats. About $1.5 \mathrm{~m} 2$ of barn floor area should be provided for goats, while about 2.5-3.0 $\mathrm{m} 2$ of barn floor area should be provided for goats / rams (Radivojević, 2013).

One of the most important factors on which the profitability of goat production depends is the possibility of providing sufficient quantities of bulky and concentrated food. In our climatic conditions, corn silage or grass-clover silage is most often used for feeding goats. The amount of silage in the daily meal for goats ranges from 2-4 kg, and pregnant goats are given in the amount of 1-2 kg (Mirić et al., 1996).

Profit in goat production largely depends on the direction of production and racial composition of goats. The largest part of the income from goat farms is realized through the sale of milk or dairy products. Therefore, the income mostly depends on the milk yield of goats that are raised and the price of milk on the market. Apart from milk and dairy products, a significant income is from the sale of kids, whether they are fattening or breeding heads. Therefore, the subject of this research is the profitability of goat breeding. The aim of the research in this paper is to find answers to some important questions, such as: What amount of profit can he expect from goat breeding? Is such production, for the producer, economically justified? For what period of time can the investments in a goat farm be returned and at what rate of accumulation?

\section{Materials and Methods}

The available production capacities and investments for the adaptation of the facilities and the procurement of the breeding herd and the necessary equipment for the farm on the farm were determined on the basis of data obtained from goat breeders in our practice. Data from the database of the Republic Statistical Office of Serbia were used for the research (SORS, 2020) namely: Statistical Yearbooks, publication - Census of Agriculture in Serbia 2012, etc. Then, data from the statistical database of the Food and Agriculture Organization of the United Nations were used (FAO, 2020). Also, professional literature was used for certain natural inputs, care and protection of animals during breeding on the family farm. Statistical and calculative methods were used to process the collected data. The economic justification of goat breeding was determined using statistical methods for investment evaluation: return on capital, accumulation rate, average net profit and economy. Based on different criteria, assessments of the economic justification of goat breeding on the family holding are given. 


\section{Results and Discussions}

Goat milk and meat production in the world, Europe and the EU - Goat milk production in the world, from over one billion head of goats, amounts to about 18.6 million tons, of which $15.14 \%$ in Europe (2.8 million tons). There are over 15 million dairy goats in the EU. In the total production of goat milk in the EU in the amount of 2.2 million tons, the largest share belongs to Greece (26.16\%), followed by France $(27.45 \%)$, followed by Spain $(22.85 \%)$ and the Netherlands $(11.47 \%)$, and the other members together have a share of $12.07 \%$ (Table 1).

Table 1. Dairy goat population and milk production in the main countries in the Evropen Union, in the Evrope and in the World

\begin{tabular}{|l|r|c|c|c|}
\hline \multirow{2}{*}{$\begin{array}{c}\text { Country } \\
\text { Continent }\end{array}$} & \multicolumn{2}{c|}{ Population } & \multicolumn{2}{c|}{ Milk production } \\
\cline { 2 - 5 } & No. of head & Share (\%) & Tonnes & Share (\%) \\
\hline Greece & $6,300,000$ & 41.56 & 562,491 & 26.16 \\
\hline Spain & $3,059,731$ & 20.19 & 491,374 & 22.85 \\
\hline Rumania & $1,483,100$ & 9.78 & - & - \\
\hline France & $1,223,816$ & 8.07 & 590,000 & 27.45 \\
\hline Holland & 532,870 & 3.52 & 246,562 & 11.47 \\
\hline Other countries & $2,558,204$ & 16.88 & 259,612 & 12.07 \\
\hline European Union-27 & $15,157,721$ & 100.00 & $2,150,039$ & 100.00 \\
\hline Europe & $19,290,067$ & 18.65 & $2,824,715$ & 15.14 \\
\hline World & $1,034,406,504$ & 100.00 & $18,656,727$ & 100.00 \\
\hline
\end{tabular}

Source: Author's calculation according to the data FAOSTAT, Live animals and livestock processed stats, 2020, http://www.fao.org/faostat/en/

The world produces about 16 million tons of sheep and goat meat (Figure 1), of which in the European Union-27, about 4 million tons (25\%) are produced, and the leading countries are Greece, France, Spain and the Netherlands, as well as after milk production (Eurostat, 2020). The sheep and goat sector in the EU is very diverse in terms of herd size, breed and production volume (Ruiz et al, 2019).

Meat is the main product of the sheep and goat sector, but other products also have a special economic significance and bring significant income, primarily in areas where milk, cheese, wool or leather products are produced by traditional methods. Some of these products have quality labels that increase their economic potential. As small as it is, goat meat production plays an important role in the UK and Ireland, where sheep meat accounts for almost $8 \%$ and $6 \%$ of total meat production, respectively. 
Figure 1. Word production of sheep and goat meat, 2018

\section{Sheep and goat meat \\ World production: \\ 16 million tonnes}

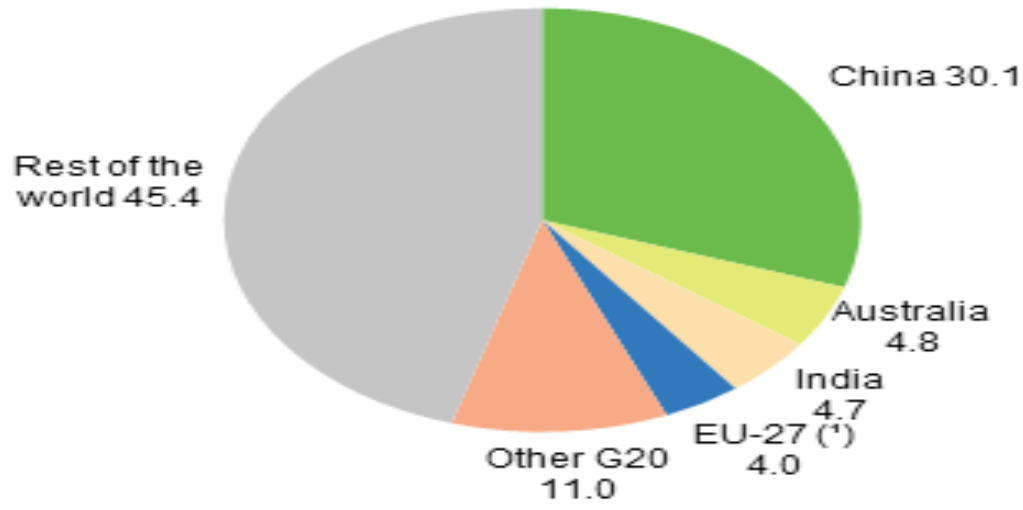

Source: FAOSTAT, http:/www.fao.org/faostat/en/

In Greece, the value of sheep and goat meat production represents almost half of the total value of livestock production. According to research, sheep and goat farming in Greece is threatened by a number of problems such as underdeveloped infrastructure, insufficient training to modernize production and increasing the degree of commercialization of products (Kitsopanidis, 2002).

Characteristics of goat breeding in the Republic of Serbia - In the Republic of Serbia, goat breeding takes place on $8 \%$ of agricultural farms (45.7 thousand), and the total number of goats is 218.4 thousand. The number of goats has been declining since 2008 with an average decline of 8.7 thousand per year. About $30 \%$ of goats are in the region of Serbia - south, while $30 \%$ are in the region of Serbia - north. The region of Sumadija and Western Serbia and the Region of Southern and Eastern Serbia have approximately the same number of goats, with $60 \%$ of the total number of heads. The average size of a herd of goats in Serbia in the northern part is 5.4 heads and 4.5 heads in the southern part. In both parts of Serbia, farms with a herd of up to 9 heads are the most represented. Territorially, most of the sheep's and goat's milk is produced in the Region of Eastern and Southern Serbia, followed by the Region of Šumadija and Western Serbia. The value of goat's milk and head for slaughter is only $0.7 \%$ of the total value of livestock production. In the total milk production in Serbia, cow's milk makes $96.84 \%$, then goat's milk 2.20, and a smaller share makes sheep's milk, 0.96\% (SORS, 2020).

Unlike all other branches of animal husbandry, goats in Serbia are mostly raised on agricultural farms, with a standard output size of less than 2,000 Euros. This category of farms $(86 \%)$ with a standard output of less than 8,000 Euros is the most numerous and they raise the largest number of goats $(76 \%)$. On medium-sized farms $(12 \%), 18 \%$ of goats are raised, and on large farms (2\%) the remaining $6 \%$ are raised. 
Economic justification of goat breeding - The profitability of goat production depends on many factors and problems that growers face. This primarily refers to the available facilities and their adaptation, then the choice of methods and systems of goat breeding, the direction of production, as well as the possibility of selling goat products - milk, kids, manure, etc. When deciding to raise goats, it is important to consider the possibility of providing a sufficient amount of food throughout the production year. Based on that, the number of goats that need to be bred is determined.

A very important issue is the size of the stock with which the production is planned to start. The accommodation and feeding capacities on the farm influents to whether a larger number of goats will start immediately or that number will increase from year to year. If the breeder does not have much experience in raising goats, production should start with a smaller number of heads, with a tendency to increase the size of the stock from year to year. An important factor on which the success of goat breeding depends is the facilities, spatial and microclimatic conditions of keeping and accommodation. Goat stable should be built according to the technical and technological requirements and needs of certain categories of goats. In addition to the shed itself, it is very often necessary to build silo facilities, hay canopies and other necessary ancillary facilities on the farm. The amount of investment in the facilities will, above all, depend on the number of goats on the farm, as well as on whether it is planned to expand the production capacity in the coming period. If an existing facility is being renovated, efforts must be made to comply with all norms provided for goatherds regarding the welfare of goats.

According to the data on existing farms in practice (farm 1 - alpine goat; farm 2 Balkan goat), input-output parameters for economic analysis were determined and investments in fixed and working capital for farms of 80 goats were estimated in the amount of $17,700 €$ and to: stable facilities - goat barn and other ancillary facilities (for renovation) in the amount of $4,200 €$; milking equipment, machinery, etc .: in the amount of 5,700 $€$; investments in the breeding herd 6,400 $€$ and working capital in the amount of $1,400 €$. For the stable-pasture system of breeding, the production of 500 liters of milk is planned, 1.7 kids per year per goat. Goats are sold when they reach a body weight of $15 \mathrm{~kg}$, and for breeding they are included with $35 \mathrm{~kg}$.

Both the production itself and the accuracy of financial results in the calculation are influenced by numerous factors, so it is more realistic to make a calculation and financial analysis of goat production for each individual farm, than to apply a general one in which average values are taken for the most important parameters. The parameters for the analysis of farms in this research should be taken only as a guide, because the included prices are very susceptible to variation from year to year.

A rough estimate of the profitability of goat milk and meat production was made on the basis of head productivity in average breeding conditions. Quality grass mass meets protein needs, but the problem of meeting energy needs remains. In addition to bulky nutrients, goats should be given concentrated nutrients. The most commonly used are corn, oats, barley, wheat, heat-treated soybeans, beans, peas, bran, fodder flour, 
soybeans and sunflower cakes. Appropriate mixtures of concentrated nutrients can be used in the diet of certain categories of goats.

Food and nutrition are the most important items of economics of goat breeding. The goat's meal should be sufficient in all phases of the reproductive cycle, both in terms of quantity and quality. Table 2 shows the different models of daily meals for goats.

Table 2. Meal models for daily feeding of goats per head *

\begin{tabular}{|l|c|c|c|}
\hline \multirow{2}{*}{$\begin{array}{c}\text { Type of nutrients } \\
\text { (kg/day) }\end{array}$} & \multicolumn{3}{c|}{ Meal per head } \\
\cline { 2 - 4 } & Model 1 & Model 2 & Model 3 \\
\hline Red clover + grass (pasture) & - & 2.5 & - \\
\hline Corn silage & 2.5 & - & - \\
\hline Meadow hay & 1.5 & - & - \\
\hline Alfalfa hay in bloom & - & 0.8 & 1.5 \\
\hline Silage of beans + oats & - & - & 1.8 \\
\hline Corn, grain & 0.3 & 0.6 & 0.6 \\
\hline Potatoes, steamed & - & - & 0.7 \\
\hline Sunflower cake & 0.3 & - & - \\
\hline Bran, wheat & - & 0.5 & - \\
\hline Fodder salt & 0.015 & 0.015 & 0.015 \\
\hline & 2.5 & 2.3 & 2.5 \\
\hline Dry matter (kg) & 14.53 & 14.2 & 14.2 \\
\hline NEL (MJ) & 223.5 & 233.0 & 232.0 \\
\hline Digestible proteins (g) & 16.0 & 17.0 & 23.3 \\
\hline Calcium (g) & 10.6 & 11.0 & 8.0 \\
\hline Phosphorus-total (g) & \multicolumn{3}{|l}{} \\
\hline
\end{tabular}

* The body weight of the throat is $60 \mathrm{~kg}$; production per head $3 \mathrm{~kg}$ of milk with $3.5 \%$ milk fat;

NEL - net energy in lactation; MJ - mega Julie

Source: According to the norms of Obračević et al., 1990

The study analyzed two farms that differ in goat breeds. Farm 1 raises an alpine goat or a French alpine goat. This is a breed of domestic goat, which originates from the French Alps. The average weight of a female is $60-80 \mathrm{~kg}$, and a goat $80-100 \mathrm{~kg}$. The milk yield of goats of this breed is 500-800 liters during one the lactation whose lasts about 280 days. She is extremely appreciated for her milk yield. Domestic Balkan goat is bred on farm 2. This is a typical example of primitive races with less productive traits. It is most widespread in the hilly and mountainous areas of our country. Their average weight is $34-40 \mathrm{~kg}$. She is fertile from the age of 2. Usually 1-2 kids goats. Lactation lasts 7-8 months. It is very resistant to low temperatures. The species is endangered and it is estimated that there are less than 1,000 heads in Serbia.

On the basis of average racial values for fertility, milk production and fertilizers in the barn, in Table 3, the average income and costs for farms of 80 heads each, for alpine and Balkan goats, were determined by a calculation procedure. 
Table 3. Gross income from goat breeding on the farm, 80 heads

(Eura)

\begin{tabular}{|l|l|c|c|}
\hline \multicolumn{2}{|c|}{ Economic indicators } & Farm 1 - Alpine Goat & Farm 2 - Balkan Goat \\
\hline I & Revenues (without incentives)* & $\mathbf{2 6 . 1 5 0}$ & $\mathbf{1 6 . 4 2 0}$ \\
\hline & Milk & 16,800 & 9,400 \\
\hline & Goatling & 7,875 & 6,030 \\
\hline & Excreted heads (goats) & 1,475 & 990 \\
\hline & Manure ** & - & - \\
\hline II & Production costs & $\mathbf{8 , 1 1 0}$ & $\mathbf{6 , 7 5 0}$ \\
\hline & Food & 7,090 & 5,960 \\
\hline & Workers' work & 450 & 340 \\
\hline & Veterinary services & 340 & 270 \\
\hline & Other expenses & 230 & 180 \\
\hline III & Gross profit (I-II) & $\mathbf{1 8 , 0 4 0}$ & $\mathbf{9 , 6 7 0}$ \\
\hline
\end{tabular}

* In the Republic of Serbia in 2020, incentives for goats amount to 7,000 RSD per head ** Manure is used to fertilize the area on the farm

Note: The calculation is made on the example of a herd intended for meat and milk production

The most important product in dairy breeds of goats is milk. Its production is conditioned by the production-racial type of goats, then by feeding, keeping and exploiting animals. Another important place has meat. Its quantities depend on the intensity and length of fattening kids. Dairy goats produce good quality goat meat. In third place comes manure of good quality.

Goat's milk is used as a dietary food in a smaller part in the fresh state, and a larger part is used for cheese production. For $8 \mathrm{~kg}$ of mature-hard cheese, about 8 liters of goat's milk are needed, and for soft cheese, about 6.5-7 liters. Course of lactation and milk production have their specifics and they depend on: the order and length of lactation, daily milk production and its durability, the period of drying and nutrition of goats. Favorable prices of milk, goat meat, dried goat meat, the possibility of processing goat meat into quality durable cured meat products, as well as incentives from the state, are increasingly attracting the attention of goat breeders in the Republic of Serbia.

On the basis of economic parameters determined by the calculation procedure for one production cycle of hair keeping (Table 3), cash flows for the five-year period of goat farms of the stated breeds of 80 heads were projected and selected economic indicators were determined on their basis (Table 4). 
Table 4. Cash flows from goat breeding on the holding, 80 head

\begin{tabular}{|c|c|c|c|c|c|c|}
\hline \multirow{2}{*}{$\begin{array}{l}\text { R. } \\
\text { no. }\end{array}$} & \multirow{2}{*}{$\begin{array}{l}\text { Economic } \\
\text { indicators }\end{array}$} & \multicolumn{5}{|c|}{ Amounts per years $(€)$} \\
\hline & & 1st year & 2nd year & 3rd year & 4th year & 5th year \\
\hline \multicolumn{7}{|c|}{ Farm 1 - Alpine Goat } \\
\hline 1. & Total revenue & 26,150 & 26,750 & 26,550 & 26,850 & 26,680 \\
\hline 2. & Total expenses & 8,110 & 8,350 & 8,750 & 7,980 & 7,850 \\
\hline 3. & Gross profit & 18,040 & 18,400 & 17,800 & 18,870 & 18,830 \\
\hline 4. & Income tax & 180 & 184 & 178 & 189 & 188 \\
\hline 5. & Net profit & 17,860 & 18,216 & 17,622 & 18,681 & 18,642 \\
\hline \multicolumn{7}{|c|}{ Farm 2 - Balkan Goat } \\
\hline 1. & Total revenue & 16,420 & 16,850 & 16,980 & 16,760 & 16,390 \\
\hline 2. & Total expenses & 6,750 & 6,650 & 6,490 & 6,390 & 6,830 \\
\hline 3. & Gross profit & 9,670 & 10,200 & 10,490 & 10,370 & 9,560 \\
\hline 4. & Income tax & 967 & 102 & 105 & 104 & 96 \\
\hline 5. & Net profit & 8,703 & 10,098 & 10,385 & 10,266 & 9,464 \\
\hline
\end{tabular}

Source: Author's calculation according to goat breeding data on holdings

For the purpose of obtaining an assessment of the economic justification of the mentioned goat farms, static methods were applied. During the analysis, data from 2019 of production were taken as representative economic parameters. The final amounts of economic indicators determined by calculation procedures are given in the final amount in Table 5 .

Table 5. Indicators of economic justification of goat breeding on the holding, 80 heads

\begin{tabular}{|l|c|c|c|}
\hline Economic indicators & $\begin{array}{c}\text { Unit of } \\
\text { measure }\end{array}$ & $\begin{array}{c}\text { Farm 1 } \\
\text { - Alpine Goat }\end{array}$ & $\begin{array}{c}\text { Farm 2 } \\
\text { - Balkan Goat }\end{array}$ \\
\hline Average net profit & $€$ & 18,208 & 9,783 \\
\hline Coefficient of economy & - & 3.24 & 2.52 \\
\hline Accumulation rate & $\%$ & 102.85 & 55.27 \\
\hline Return on investment time & years & 0.97 & 1.81 \\
\hline
\end{tabular}

Source: Author's calculation based on results for a five-year period of goat breeding

Based on the established indicators, it can be concluded that by breeding alpine goats (farm 1 ); the coefficient of economy is 3.24 . According to the required criteria, the coefficient is higher than one, so from this aspect the production is economical, i.e. economically justified for the breeder. The average net profit is $18,208 €$ and since it is positive and significantly above zero, production is economically efficient. The accumulation rate is $102.85 \%$ and is far above the limit, for which in this case it is taken as $20 \%$ which confirms that the production is economically justified. The investment of the amount of money can be returned in the first year of goat breeding and the period is significantly shorter than the analyzed economic period, i.e. of five years, so even according to this criterion, production is economically acceptable.

On farm 2, of the Balkan goat breed, the coefficient of economy is 2.52 and is higher than one, which means that the production is economical. The average net profit is $€$ 
9,783 and is significantly above zero, which means that production is economically justified. The net profit from farm 2 is significantly less than the net profit farm 1, i.e. 9,783 Euro less than 18,208 Euro.

Based on the obtained accumulation rate of $55.27 \%$, it can be seen that at 100 Euros of invested capital in production, about 55 euro of accumulation are achieved. Since the accumulation rate is far higher than the marginal accumulation rate, i.e. of $20 \%$, production is acceptable. The obtained result shows that the capital invested in goat breeding can be returned in the second year of the production cycle. Considering that the determined period of 1.81 years is shorter than the economic limit, i.e. of five years, means that according to this criterion, the breeding of Balkan goats for the producer is economically justified. Based on the analysis, both of the goat farms achieve significant economic benefits, but the economic results from farm 1 (Alpine goat) are more favorable than farm 2 (Balkan goat).

Extensive production systems and general conditions provide the possibility of production of these primary products with environmental values. The profitability of production must be found in the placement on the market with ecological and autochthonous products. Therefore, it is necessary to "enrich" the produced milk by processing it into an attractive dairy product with a geographical origin, which could achieve about $30 \%$ higher price on the market compared to related foods.

\section{Conclusions}

Goat milk production in the world, from over one billion head of goats, amounts to about 18.6 million tons, of which $15.14 \%$ in Europe (2.8 million tons). There are over 15 million dairy goats in the EU. In the total production of goat milk in the EU in the amount of 2.2 million tons, the largest share belongs to Greece (26.16\%), followed by France $(27.45 \%)$, followed by Spain $(22.85 \%)$ and the Netherlands $(11.47 \%)$, and other members of the group participate with $12.07 \%$. The world produces about 16 million tons of meat from sheep and goats, of which in the European Union-27, about 4 million tons $(25 \%)$ are produced, and the leading countries are Greece, France, Spain and the Netherlands, as well as by production milk. The sheep and goat sector in the EU is very diverse in terms of herd size, breed and production volume. In the Republic of Serbia, goat breeding takes place on $8 \%$ of agricultural farms (45.7 thousand), and the total number of goats is 218.4 thousand. The number of goats has been declining since 2008 with an average decline of 8.7 thousand per year. The average size of a herd of goats in Serbia in the northern part is 5.4 heads and 4.5 heads in the southern part. Territorially, most of the sheep's and goat's milk is produced in the Region of Eastern and Southern Serbia, followed by the Region of Šumadija and Western Serbia. The value of goat's milk and head for slaughter is only $0.7 \%$ of the total value of livestock production. In the total milk production in Serbia, cow's milk makes 96.84\%, then goat's milk 2.20, and a smaller share makes sheep's milk, $0.96 \%$.

Goats in Serbia are mostly bred on agricultural farms, with a standard output size of less than 2,000 Euros. This category of farms (86\%) with a standard output of less than 8,000 Euros is the most numerous and they raise the largest number of goats (76\%). According 
to the established economic indicators of alpine goat breeding (farm 1), the coefficient of economy is 3.24, and for Balkan goat breeding, it is 2.52 (farm 2). The net profit of farm 2 is significantly less than the net profit of farm 1, i.e. 9,783 euro less than 18,208 euro. At 100 Euros of invested capital $102.85 €$ of accumulation from farm 1 and $55.27 €$ from farm 2 are achieved. The invested capital in goat breeding can be returned in the first year of alpine goat breeding and in the second year by breeding Balkan goats. Based on the analysis, both of the goat farms achieve significant economic benefits.

Goat breeding on family farms is suitable for integration with other productions on the farm and they are suitable for breeding by organic production methods. The basic incentives from the budget of the Republic of Serbia amount to 7,000 RSD per head of goat, and in organic production they are much higher, in the amount of 28,000 RSD per head of goat, which makes it a chance for breeders. By investing in capacities for finishing and processing of products obtained from goat breeding, the development of other activities is encouraged, and thus the small economy in the area. In addition to the numerous economic and environmental effects achieved by goat breeding, this production also has social significance and provides an opportunity for economic sustainability of family farms in rural areas.

\section{Acknowledgements}

The paper is the result of research within the contract on the implementation and financing of scientific research in 2020 of the Ministry of Education, Science and Technological Development of the Republic of Serbia and researchers at the Faculty of Agriculture, Belgrade-Zemun, and No. 451-03-68/2020-14/200116.

\section{Conflict of interests}

The authors declare no conflict of interest.

\section{References}

1. Bogdanović, V., Đorđević, I. \& Đurđević, I. (2008). Osobine mlečnosti balkanske koze u poluekstenzivnim uslovima gajenja, Biotechnology in Animal Husbandry, 24(1-2), 2008 ISSN 1450-9156 Publisher: Institute for Animal Husbandry, Belgrade-Zemun, p 59-67 [in English: Bogdanović, V., Đorđević, I. Đurđević, I. (2008). Milk characteristics of Balkan goat in semi-extensive breeding conditions Biotechnology in Animal Husbandry 24 (1-2), 2008 ISSN 1450-9156 Publisher: Institute for Animal Husbandry, Belgrade-Zemun, pp. 59-67].

2. Coffey, L., Wells, A., \& Earles. R. (2001). Sustainable goat production, overview. ATTRA. University of Arkansas. Fayetteville.

3. FAOSTAT (2020). Live animals and livestock processed stats. Food and Agriculture Organization of the United Nations, Rome, Italy, FAO, Retrieved from http://www. fao.org/faostat/en/ (September 23, 2020) 
4. Goddard, P., Waterhouse, T., Dwyer, C., \& Stott, A. (2006). The perception of the welfare of sheep in extensive systems. Small Ruminant Research, 62(3), 215-225.

5. Kitsopanidis, I. G. (2000). Economics of dairy farming in Greece. Medit, 11(4) 49-55.

6. Kitsopanidis, G.I. (2002). Economics of goat farming in Greece. New medit, 1(3), 48-53.

7. Mirić, M., Milojković, J., \& Spasić, Z. (1996). Savremeno kozarstvo. Institut za stočarstvo i veterinarstvo. Priština [in English: Mirić, M., Milojković, J., Spasić, Z. (1996). Modern goat breeding. Institute of Animal Husbandry and Veterinary Medicine. Priština].

8. Obračević, Č. (1990). Tablice hranljivih vrednosti stočnih hraniva $i$ normativi $u$ ishrani preživara. Beograd. [In English: Obračević, Č. (1990). Tables of nutritional values of animal feed and norms in ruminant nutrition. Belgrade].

9. Ocokoljić, S., Mijatović, M., Čolić, D., Bošnjak, D., \& Milošević, P. (1983). Prirodni i sejani travnjaci. Nolit, Beograd. [In English: Ocokoljić, S., Mijatović, M., Čolić, D., Bošnjak, D., Milošević, P. (1983). Natural and sown lawns.Nolit. Belgrade].

10. Pavličević, A. Grubić, G., Mekić, C., Bogavac, V., \& Stojković, M. (2000). Uticaj ishrane gravidnih ovaca na prinos vune i telesnu masu jagnjadi. Arhiv za poljoprivredne nauke, 61(3), 143-150. [In English: Pavličević, A. Grubić, G., Mekić, C., Bogavac, V., \& Stojković, M. (2000). Influence of pregnant sheep diet on wool yield and body weight of lambs. Archives of Agricultural Sciences, 61(3), 143-150].

11. RZS (2020). Stočarstvo u Republici Srbiji, prema popisu poljoprivred u Republici Srbiji, 2012, Retrieved from http://webrzs.stat.gov.rs/WebSite/ (November 15, 2020).

12. Ruiz, M., F.A., Castel, G., J. M., \& Guerrero, Y. M. (2019). Current status, challenges and the way forward for dairy goat production in Europe. Asian-Australasian journal of animal sciences, 32(8), 1256-1265. https://doi.org/10.5713/ajas.19.0327

13. Radivojević, D. (2013). Mehanizacija, objekti i oprema. Beograd: Posebna publikacija RZS. [In English: Radivojević, D. (2013). Mechanization, facilities and equipment. Belgrade: Special publication of the SORS].

14. Sehested, J., Soegaard, K., Danielsen, V., \& Kristensen, V.F. (2000). Mixed grazing with sows and heifers: effects on aniaml performance and pasture. Ecological Animal Husbandry in the Nordic Countries.

15. Stojanović, B., Adamović, O., \& Grubić, G. (2004). Unapređenje strategije ishrane domaćih životinja u cilju smanjenja negativnih uticaja na životnu sredinu. III Među-narodna Eko-konferencija, Tematski zbornik, Novi Sad, 99-104 [in English: Stojanović, B., Adamović, O., Grubić, G. (2004). Improving the strategy of feeding domestic animals in order to reduce the negative impact on the environment. III International Eco-Conference, Thematic Proceedings, Novi Sad, 99-104].

16. Qushim, B., Gillespie, \& J., McMillin (2016). Meat Goat Enterprise Efficiency Analysis in the Southeastern United States. Journal of Agricultural and Applied Economics, 48(1), 52-72.

17. Wells, A., Gegner, L., Earles, R. (2000). Sustainable Sheep Production. Livestock Production Guide. University of Arkansas, Fayettewille. 